\title{
ANALISA KINERJA MESIN DIESEL BERBAHAN BAKAR CAMPURAN SOLAR DAN MINYAK PLASTIK
}

\author{
Untung Surya Dharma ${ }^{1}$, Eko Nugroho ${ }^{3}$, M. Fatkurahman ${ }^{3}$ \\ Jurusan Teknik Mesin, Universitas Muhammadiyah Metro \\ Jl. Ki Hajar Dewantara No. 116 Metro, Lampung, Indonesia \\ Email : Untungsdh@yahoo.co.id ${ }^{1}$, exonugros@gmail.com², m.fatkurahman123@yahoo.com³
}

\begin{abstract}
Abstrak
Dari penelitian terdahulu di tahun 2015 diketahui minyak plastik dapat digunakan sebagai campuran bahan bakar premium pada sepeda motor, namun tidak diizinkan apabila diaplikasikan dalam jumlah banyak karena semakin banyak minyak plastik sebagai campuran premium maka nilai torsi dan daya yang dihasilkan mesin sepeda motor akan semakin rendah, sedangkan konsumsi bahan bakar akan semakin besar (boros). Dari hasil penelitian tersebut maka penelitian lebih lanjut telah dilakukan dengan mengaplikasikan minyak plastik sebagai campuran bahan bakar solar pada mesin diesel. Tujuan dari penelitian lanjutan ini adalah untuk menganalisa kinerja mesin diesel akibat pengaruh minyak plastik sebagai campuran bahan bakar solar. Metode yang digunakan adalah pengaplikasian minyak plastik sebagai campuran solar pada Mesin Diesel Merk/Type ROBIN-FUJIDY23D dengan perbandingan 100\%:0\% (solar tanpa campuran minyak plastik), 88\%:12\%, 85\%:15\% dan 82\%:18\%. Parameter pengujian yang digunakan dalam menentukan prestasi mesin pada putaran mesin 2900 sampai dengan 3500 rpm menghasilkan torsi motor, daya motor, konsumsi bahan bakar spesifik, dan efisiensi thermal. Hasil penelitian secara umum menunjukan bahwa kinerja mesin diesel berbahan bakar campuran antara solar dengan minyak plastik akan menurun seiring dengan semakin banyaknya minyak plastik yang digunakan apabila dibandingkan dengan penggunaan solar $100 \%$. Sedangkan pada putaran tinggi dan pembebanan yang besar, perbedaan daya yang dihasilkan hampir tidak begitu signifikan dan mendekati daya maksimum yang dapat dihasilkan berdasarkan spesifikasi mesin yaitu 3,5 kW. Hal yang sama juga untuk hasil pengujian torsi dan efisiensi thermal. Sedangkan untuk konsumsi bahan bakar menunjukan bahwa semakin banyak minyak plastik maka konsumsi bahan bakar akan semakin boros.
\end{abstract}

Kata Kunci: Kinerja Mesin Diesel, Campuran Minyak Plastik-Solar.

\section{PENDAHULUAN}

Dari penelitian Untung tahun 2015, sebelumnya diketahui bahwa minyak plastik yang dihasilkan dengan cara dua kali proses pirolisis hanya dapat dimanfaatkan sebagai zat aditif atau campuran bahan bakar pada mesin bensin [1]. Pada Penelitian tersebut, minyak plastik yang dipakai berasal dari proses pembuatan dengan cara dua kali proses pirolisis. Suhu reaktor pada proses pirolisis yang pertama dan kedua berbeda berturutturut yaitu $200 \quad{ }^{\circ} \mathrm{C}$ dan $150 \quad{ }^{\circ} \mathrm{C}$. Karakteristik dasar minyak plastik yang dihasilkan adalah massa jenis $771,4 \mathrm{~kg} / \mathrm{m}^{3}$,
Viskositas $0,501 \mathrm{~m}^{2} / \mathrm{s}$ dan Nilai kalor $10518 \mathrm{~kJ} / \mathrm{kg}$ [2].

Untuk mengetahui pengaruh minyak plastik terhadap prestasi mesin bensin, Untung di tahun 2015 melakukan pengaplikasian langsung pada sepeda motor merk-X dengan spesifikasi teknis volume silinder $179,8 \mathrm{~cm}^{2}$, Tekanan Pembakaran $98 \mathrm{~N} / \mathrm{cm}^{2}$, Torsi maksimum 15,22 Nm pada $6000 \mathrm{rpm}$, Daya maksimum 12,15 kW pada $8000 \mathrm{rpm}$. Pengambilan data dilakukan pada dua kondisi yaitu kondisi stasioner untuk mengukur torsi yang terjadi dan konsumsi bahan bakar untuk menghitung daya dan 
pemakaian bahan bakar spesifik. Pengambilan data pada road test untuk mendapatkan nilai akselerasi dan pemakaian bahan bakar pada kondisi real di jalanan [2].

Dari data-data pengujian dan hasil perhitungan dari ketiga variasi campuran diketahui bahwa pada campuran perbandingan minyak plastik-premium adalah 1:4 menghasilkan torsi dan daya mendekati nilai premium murni tanpa campuran yaitu sebesar 12,55 $\mathrm{Nm}$ dan $7,88 \mathrm{~kW}$ pada $6000 \mathrm{rpm}$ dengan nilai percepatan yang lebih baik. Konsumsi bahan bakar pada saat pengujian stasioner uji torsi sebesar $0,72 \mathrm{~kg} / \mathrm{jam}$ pada 6000 rpm dan pada saat road test hanya sebesar 0,41 liter pada kecepatan $100 \mathrm{~km} / \mathrm{jam}$. Secara keseluruhan penelitian Untung (2015) disimpulkan bahwa semakin banyak campuran minyak plastik (2:3 dan 3:4) maka nilai torsi dan daya yang dihasilkan mesin sepeda motor akan semakin rendah, sedangkan konsumsi bahan bakar akan semakin besar (boros) [1].

Dari penjelasan diatas, penelitian lebih lanjut tentang penggunaan minyak plastik dari limbah plastik sebagai campuran bahan bakar diaplikasikan secara langsung pada mesin diesel dirasakan perlu untuk mengetahui pengaruhnya terhadap kinerja suatu mesin diesel, apabila ditinjau dari segi penghematan energi, lingkungan hidup dan beberapa faktor lainnya yang menyangkut energi terbarukan, guna mendukung pemamfaatan sumber daya energi terbarukan.

\section{TINJAUAN PUSTAKA}

\section{Bahan Bakar Minyak Plastik}

Bahan bakar adalah suatu bahan (material) yang apabila dibakar akan menghasilkan energi panas. Setiap bahan bakar memiliki karakteristik dan nilai pembakaran yang berbeda-beda. Karakteristik inilah yang menentukan sifat-sifat dalam proses pembakaran, dimana sifat yang kurang menguntungkan dapat disempurnakan dengan jalan menambah bahan-bahan kimia ke dalam bahan bakar tersebut.

Untuk bahan bakar cair, khususnya bensin atau solar biasanya ditambahkan bahan-bahan aditif dengan harapan akan mempengaruhi daya anti knocking atau daya letup dari bahan bakar, dan dalam hal ini menunjuk apa yang dinamakan dengan bilangan oktan (octane number) atau angka cetan (Cetane Number) pada solar. Cetane Number (Angka Setana) adalah ukuran yang menunjukan kualitas dari bahan bakar untuk diesel. Untuk mesin diesel umumnya menggunakan bahan bakar angka setana antara 40 - 55. Bahan bakar dengan angka setana tinggi akan memiliki periode pengapian lebih pendek daripada berbahan bakar dengan angka setana rendah, atau dengan kata lain semakin tinggi angka setana maka semakin mudah bahan bakar untuk terbakar secara kompresi.

Plastik memiliki banyak kelebihan dibandingkan bahan lainnya. Secara umum, plastik memiliki densitas yang rendah, bersifat isolasi terhadap listrik, mempunyai kekuatan mekanik yang bervariasi, ketahanan suhu terbatas, serta ketahanan bahan kimia yang bervariasi. Selain itu, plastik juga ringan, mudah dalam perancangan, dan biaya pembuatan murah. Sebagian besar plastik yang digunakan masyarakat merupakan jenis plastik polietilena. Ada dua jenis polietilena, yaitu high density polyethylene (HDPE) dan low density polyethylene (LDPE). HDPE banyak digunakan sebagai botol plastik minuman, sedangkan LDPE untuk kantong plastik.

Karakteristik utama minyak plastik sebagai campuran bahan bakar dari hasil penelitian-penelitian terdahulu dapat dilihat pada Tabel 1 di bawah ini. 
Tabel 1. Karakteristik Utama Minyak Plastik dari Beberapa Penelitian $[3,4,5,6]$

\begin{tabular}{|c|c|c|c|c|c|c|}
\hline No & Karakteristik & $\begin{array}{l}\text { Untung } \\
(2015)\end{array}$ & $\begin{array}{l}\text { Mahendro, } \\
\text { dkk } \\
(2013)\end{array}$ & $\begin{array}{l}\text { Tamilkundo } \\
\& \\
\text { munugusen } \\
(2012)\end{array}$ & $\begin{array}{l}\text { Aprian \& } \\
\text { Munawar } \\
\text { (2011) }\end{array}$ & $\begin{array}{l}\text { Joko } \\
\text { Santoso } \\
(2010)\end{array}$ \\
\hline 1 & $\begin{array}{l}\text { Suhu reaktor } \\
\text { Pirolisis }\left({ }^{\circ} \mathrm{C}\right)\end{array}$ & $\begin{array}{ll}200 & \& \\
150 & \\
\end{array}$ & $400-500$ & 450 & 420 & 350 \\
\hline 2 & $\begin{array}{l}\text { Viskositas } \\
\text { (cP) }\end{array}$ & 0,501 & 0,721 & 0,2149 & 0,162 & 0,57 \\
\hline 3 & $\begin{array}{l}\text { Massa jenis } \\
(\mathrm{kg} / \mathrm{L})\end{array}$ & 0,7714 & 0,75 & 0,793 & - & 0,75 \\
\hline 4 & $\begin{array}{l}\text { Nilai kalor } \\
(\mathrm{kJ} / \mathrm{kg})\end{array}$ & 10517,6 & - & 41858 & 10885 & 43330 \\
\hline
\end{tabular}

Dari tabel di atas terlihat bahwa minyak plastik yang dihasilkan dari proses pirolisis dengan suhu reaktor antara $350^{\circ} \mathrm{C}$ sampai dengan $450^{\circ} \mathrm{C}$ memiliki karakteristik yang hampir sama. Selain karakteristik diatas, Berdasarkan persetujuan Prinsip Dirjen Migas No. 940/34/DJM.O/2002 tanggal 2 Desember 2002 tentang standar bahan bakar cair maka nilai spgr untuk solar yaitu sebesar 0,8514, Nilai ${ }^{\circ}$ API yaitu $35-39$ dan Nilai setana (Cetane Number) sebesar 51 [7]. Dari standar tersebut, Putri Apriani (2011) telah melakukan penelitian tentang minyak plastik dari limbah plastik dengan hasil pengujian hampir mendekati nilai-nilai standar dari Dirjen Migas tersebut yaitu nilai spgr sebesar 0,8514 , Nilai ${ }^{\circ}$ API yaitu 34,6968 water content sebesar 453,33 ppm, Sulphur content sebesar 85,5 ppm, Flash point sebesar $41{ }^{\circ} \mathrm{C}$ dan dan centane number sebesar 51,5 [8].

\section{Mesin Diesel}

Konsep pembakaran pada mesin diesel berbeda dengan pembakaran pada mesin bensin. Konsep pada mesin diesel adalah penyalaan kompresi udara paada tekanan tinggi. Pembakaran dapat terjadi karena udara dikompresi pada ruang bakar. Akibatnya udara akan mempunyai tekanan dan temperatur melebihi suhu dan tekanan penyalaan bahan bakar.

Siklus diesel secara teori untuk compression ignition engine pada motor diesel, penambahan panas terjadi pada tekanan tetap ( $\mathrm{P}-\mathrm{V}$ Diagram) sehingga siklus diesel disebut juga siklus tekanan tetap ketika proses pembakaran terjadi di dalam silinder (Gambar 1).

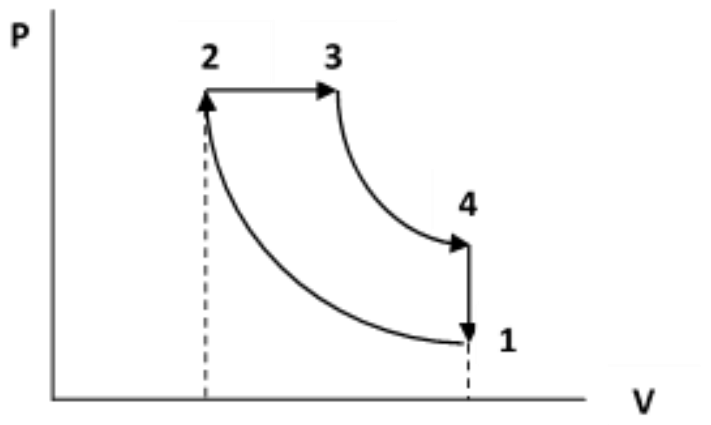

Gambar 1. Diagram P-V

Dari gambar 1, diketahui bahwa :

1-2 : langkah kompresi isentropis adiabatis

2 - 3 : Penginjeksian bahan bakar (proses pembakaran) pada kondisi isobaris

$3-4$ : Ekspansi isentropis adiabatis

$4-5$ : Pembakaran kalor isochoric, pelepasan kalor (gas buang ke udara)

Diagram P-V pada mesin diesel diatas merupakan siklus ideal yaitu siklus tanpa memperhatikan adanya kerugiankerugian kerja dalam suatu sistem. Padahal pada kerja sesungguhnya atau kerja aktual, suatu mesin tentu saja akan mengalami kerugian-kerugian yang mengakibatkan kerja mesin berubah.

Adapun tinjauan terhadap kinerja mesin diesel berdasarkan kepada tekanan dan temperature adalah:

\section{a. Energi bahan bakar yang digunakan $\left(Q_{m}\right)$}

Kalor $Q_{m}$ untuk menaikkan tekanan dan temperatur fluida kerja siklus udara. Tetapi dalam motor bakar torak yang sebenarnya kenaikan temperatur dan tekanan fluida kerja yang diperlukan itu diperoleh dari hasil pembakaran bahan bakar dan udara di dalam silinder. Oleh karena itu energi yang dipergunakan dihitung berdasarkan jumlah energi bahan bakar tersebut, dengan persamaan:

$\dot{\mathrm{Q}}_{m}=\dot{\mathrm{G}}_{f} \times \mathrm{Q}_{c}$ 
Keterangan:

$\dot{\mathrm{Q}}_{m}$ : Energi bahan bakar yang digunakan ( $\mathrm{kcal} / \mathrm{jam})$

$\dot{\mathrm{G}}_{f}$ : Jumlah bahan bakar yang dipergunakan $(\mathrm{kg} / \mathrm{jam})$

$\mathrm{Q}_{c}$ : Nilai kalor bahan bakar $(\mathrm{kcal} / \mathrm{kg})$

Untuk $\dot{\mathrm{G}}_{f}$ dapat dicari menggunakan rumus :

$\dot{\mathrm{G}}_{f}=\frac{\rho_{f} \cdot V_{f} \cdot 10^{-3}}{t_{f}} \times 3600$

Dimana :

$\rho_{f}=$ Densitas bahan bakar

$V_{f}=$ Volume bahan bakar

$t_{f}=$ waktu untuk menghabiskan bahan bakar

b. Konsumsi bahan bakar spesifik

Konsumsi bahan bakar spesifik (B) didefinisikan sebagai jumlah bahan bakar yang dikonsumsi per satuan daya yang dihasilkan per jam operasi. Untuk mengetahui konsumsi bahan bakar spesifik dapat diketahui menggunakan persamaan berikut:

$B=\frac{\dot{\mathrm{G}}_{f}}{W_{b}}$

Keterangan:

$B$ : Konsumsi bahan bakar spesifik $\left(\frac{\mathrm{kg} / \mathrm{jam}}{\mathrm{kW}}\right)$

\section{c. Efisiensi termal}

Efisiensi termal suatu mesin didefinisikan sebagai perbandingan antara energi keluaran dengan energi kimia yang masuk dan dikandung bahan bakar yang dihisap kedalam ruang bakar. Untuk mengetahui nilai efisiensi termal digunakan persamaan berikut:

$\eta_{\text {thermal }}=\frac{\dot{\mathrm{W}}_{p}}{\dot{\mathrm{G}}_{f} \times \mathrm{Q}_{c}} \times 632$

Keterangan:

$\eta_{\text {thermal }}:$ Efisiensi termal

\section{METODELOGI PENELITIAN}

\section{Alat dan Bahan}

Penelitian ini menggunakan metode eksperimental. Alat ukur yang digunakan adalah Dinamometer Hidraulik dengan unit instrumentasi TD 114. Mesin diesel yang digunakan adalah Merk/Type ROBIN-FUJIDY23D, dengan spesifikasi sebagai berikut :

$\begin{array}{ll}\text { Jenis motor diesel } & : 4-\mathrm{Tak} \\ \text { Jumlah silinder } & : 1 \\ \text { Volume langkah torak } & : 230 \mathrm{~cm}^{3} \\ \text { Langkah torak } & : 60 \mathrm{~cm} \\ \text { Diameter silinder } & : 70 \mathrm{~mm} \\ \text { Perbandingan kompresi } & : 21 \\ \text { Torsi maksimum } & : 10,5 \mathrm{Nm} \text { pada } \\ & 2200 \mathrm{rpm} \\ \text { Daya engkol maksimum } & : 3,5 \mathrm{~kW} \text { pada } \\ & : 3600 \mathrm{rpm} \\ \text { Putaran maksimum } & : 3600 \mathrm{rpm} \\ \text { Posisi Valve } & : \text { overhead } \\ & (\mathrm{OHV})\end{array}$

Waktu injeksi bahan bakar: $23{ }^{\circ}$ BTDC

Berat : $26 \mathrm{~kg}$

Berdasarkan hasil pengujian laboratorium, minyak plastik yang digunakan memiliki sifat-sifat seperti yang ditampilkan pada Tabel 2 .

Tabel 2. Sifat-sifat Bahan Bakar Minyak Plastik yang digunakan dalam penelitian.

\begin{tabular}{|c|c|c|c|c|c|}
\hline \multirow[b]{2}{*}{ Sifat } & \multirow[b]{2}{*}{ Solar } & \multirow[b]{2}{*}{$\begin{array}{c}\text { Minyak } \\
\text { Plastik }\end{array}$} & \multicolumn{3}{|c|}{$\begin{array}{l}\text { Solar : Minyak } \\
\text { Plastik }\end{array}$} \\
\hline & & & $\begin{array}{c}88 \%: \\
12 \%\end{array}$ & $\begin{array}{c}85 \\
\%: \\
15 \\
\%\end{array}$ & $\begin{array}{c}82 \%: \\
18 \%\end{array}$ \\
\hline $\begin{array}{c}\text { Massa } \\
\text { jenis } \\
\left(\mathrm{kg} / \mathrm{m}^{3}\right)\end{array}$ & 880 & 726 & $\begin{array}{c}861,5 \\
2\end{array}$ & 856 & 851,6 \\
\hline $\begin{array}{c}\text { Nilai } \\
\text { kalor } \\
(\mathrm{kJ} / \mathrm{kg})\end{array}$ & 46,5 & 43,808 & $\begin{array}{c}46,17 \\
6\end{array}$ & $\begin{array}{l}46, \\
096\end{array}$ & $\begin{array}{c}46,01 \\
5\end{array}$ \\
\hline $\begin{array}{c}\text { Viskosit } \\
\text { as } \\
(\mathrm{kg} / \mathrm{s} . \mathrm{m})\end{array}$ & - & $\begin{array}{c}0,5906 \\
\pm \\
0,0809\end{array}$ & - & - & - \\
\hline
\end{tabular}

Sumber : Dokumentasi Hasil Pengujian Laboratorium (Untung \& $\mathrm{M}$.

Fatkurrahman, 2017) 


\section{Prosedur Penelitian}

\section{Pengkalibrasian Torsimeter TD 114}

Sebelum melakukan uji mesin, Torsimeter harus dalam posisi nol dan kalibrasi terlebih dahulu. Adapun caranya adalah sebagai berikut:

1) Hubungkan unit instrumentasi TD 114 ini dengan arus listrik, dan hidupkan unit instrumentasi TD 114 ini.

2) Putar Span Control hingga posisi Maksimum ( Searah putaran Jarum jam)

3) Guncangkan dinamometernya untuk mengatasi kekakuan seal bantalanya, vibrasi terjadi secara otomatis bila mesin berputar,.

4) Putar Zero Control hingga Torsimeter terbaca Nol.

5) Guncangkan dinamometer lagi untuk memeriksa keakuratan posisi nol tersebut.

6) Gantungkan beban sebesar $3,5 \mathrm{~kg}$ pada lengan dinamometer tersebut.

7) Guncangkan dinamometer lagi hingga pembacaan Torsi meter stabil.

8) Putar Span Control hingga Torsimeter TD 114 menunjukan bacaan 8,6 Nm.

9) Singkirkan beban $3,5 \mathrm{~kg}$ tadi, dan ulangi langkah 3- langkah 8 agar penyetelan zero dan Span controlnya benar-benar akurat.

\section{Menghidupkan Mesin}

1) Buka bahan bakar katup dari tangki (KBT) untuk mengisi bahan bakar ke dalam pipet gelas, dan tutup kembali katup tersebut.

2) Buka katup bahan bakar ke mesin KBM).

3) Buka perlahan-lahan katup air umpan Dinamometer hingga terlihat air keluar dari Dinamometer.

4) Geser sedikit tungkai gas pada motor diesel 4 langkah ini.

5) Tarik tuas starting secara cepat, ualangi hingga motornya hidup.

6) Panaskan motor hingga beberapa saat.
Prosedur Pelaksanaan Pengujian

Motor diesel 4 - Langkah.

1) Catat temperatur ruangan Laboratorium.

2) Pastikan bahan bakar tetap ada dalam pipet gelas.

3) Putar Katup KBM pada posisi maksimum ( posisi horizontal).

4) Lepaskan semua beban pada Dinamometer.

5) Geser perlahan-lahan tungkai gas hingga putaran mesin terbaca pada tachometer $2900 \mathrm{rpm}$, kemudian gantungkan beban $3 \mathrm{Kg}, 2 \mathrm{Kg}, 1 \mathrm{Kg}$ Tunggu hingga bacaan torsi dan putaran mesin terlihat stabil.

6) Geser perlahan-lahan tungkai gas hingga putaran mesin terbaca pada tachometer 3200 rpm, kemudian gantungkan beban $3 \mathrm{Kg}, 2 \mathrm{Kg}, 1 \mathrm{Kg}$ Tunggu hingga bacaan torsi dan putaran mesin terlihat stabil.

7) Geser perlahan-lahan tungkai gas hingga putaran mesin terbaca pada tachometer $3500 \mathrm{rpm}$, kemudian gantungkan beban $3 \mathrm{Kg}, 2 \mathrm{Kg}, 1 \mathrm{Kg}$ Tunggu hingga bacaan torsi dan putaran mesin terlihat stabil.

8) Setelah bacaan torsi stabil, isikan bahan bakar melewati batas nol pada pipette glass dengan membuka katup KBT, kemudian tutup kembali KBT.

9) Hitung dan catat waktu pemakaian untuk $8 \mathrm{ml}$ bahan bakar. Pada waktu yang bersamaan, catat juga putaran mesin, Torsi, Temperatur gas buang.

10) Tunggulah sampai putaran mesin stabil sebelum mengambil atau mencatat hasil pengujian yang lain. Jika dinamometer terlalu sensitif dalam mendapatkan putaran yang di inginkan, ini harus di bantu dengan menutup sebagian drain tap-nya, jangan di tutup total.

11) Pastikan air umpan di dalam dinamometer selalu mengalir, yaitu dengan memeriksa keluaranya. Pastikan air yang keluar dari dinamometer di bawah $80^{0}$ C. Jika termperaturnya lebih tinggi, tingkatkan 
aliran airnya untuk mendinginkan seal bantalan dinamometer tersebut.

\section{HASIL DAN PEMBAHASAN}

\section{Data Hasil Penelitian}

Berikut ini adalah data hasil pengujian dan perhitungan yang telah dilakukan yaitu uji torsi, daya, konsumsi bahan bakar dan efisiensi thermal, yang ditampilkan pada Tabel 3 .

Tabel 3. Data Hasil Pengujian dan Perhitungan

\begin{tabular}{|c|c|c|c|c|c|c|}
\hline $\begin{array}{c}\text { Jenis } \\
\text { Bahan } \\
\text { bakar } \\
= \\
\text { Solar } \\
: \\
\text { Miny } \\
\text { ak } \\
\text { Plasti } \\
\text { k }(\%)\end{array}$ & $\begin{array}{l}\text { Putar } \\
\text { an } \\
\text { mesin } \\
\text { (rpm) }\end{array}$ & $\begin{array}{c}\text { Beba } \\
n \\
(\mathrm{~kg})\end{array}$ & $\begin{array}{l}\text { Tors } \\
\text { i } \\
\text { (N. } \\
\mathrm{m})\end{array}$ & $\begin{array}{c}\text { Day } \\
\mathrm{a} \\
(\mathrm{k} \\
\mathrm{W})\end{array}$ & $\begin{array}{c}\text { Konsums } \\
\text { i Bahan } \\
\text { bakar } \\
\text { spesifik } \\
\text { (L/kW.Ja } \\
\text { m) }\end{array}$ & $\begin{array}{c}\text { Efisien } \\
\text { si } \\
\text { therma } \\
1 \\
(\%)\end{array}$ \\
\hline \multirow{9}{*}{$\begin{array}{c}100: \\
0\end{array}$} & 2909 & 1 & 4,1 & 1,2 & 0,3 & 31 \\
\hline & 2911 & 2 & 6,6 & 2 & 0,19 & 50 \\
\hline & 2909 & 3 & 9,2 & 2,8 & 0,14 & 68 \\
\hline & 3225 & 1 & 4,2 & 1,4 & 0,34 & 28 \\
\hline & 3210 & 2 & 6,8 & 2,3 & 0,21 & 46 \\
\hline & 3210 & 3 & 9,5 & 3,1 & 0,16 & 60 \\
\hline & 3511 & 1 & 4,3 & 1,6 & 0,4 & 25 \\
\hline & 3517 & 2 & 7 & 2,6 & 0,29 & 41 \\
\hline & 3520 & 3 & 9,6 & 3,5 & 0,18 & 54 \\
\hline \multirow{9}{*}{$\begin{array}{c}88: \\
12\end{array}$} & 2907 & 1 & 4 & 1,1 & 0,33 & 28 \\
\hline & 2903 & 2 & 6,5 & 1,9 & 0,21 & 48 \\
\hline & 2900 & 3 & 9,1 & 2,75 & 0,15 & 66 \\
\hline & 3215 & 1 & 4,1 & 1,3 & 0,37 & 25 \\
\hline & 3221 & 2 & 6,6 & 2,2 & 0,24 & 42 \\
\hline & 3224 & 3 & 9,3 & 3 & 0,17 & 56 \\
\hline & 3522 & 1 & 4,2 & 1,5 & 0,43 & 23 \\
\hline & 3529 & 2 & 6,7 & 2,5 & 0,3 & 39 \\
\hline & 3526 & 3 & 9,4 & 3,45 & 0,19 & 53 \\
\hline \multirow{9}{*}{$\begin{array}{c}85: \\
15\end{array}$} & 2929 & 1 & 3 & 0,9 & 0,44 & 22 \\
\hline & 2928 & 2 & 6 & 1,8 & 0,23 & 44 \\
\hline & 2924 & 3 & 9 & 2,71 & 0,16 & 65 \\
\hline & 3221 & 1 & 3,2 & 1,2 & 0,55 & 21 \\
\hline & 3237 & 2 & 6,2 & 2,1 & 0,27 & 37 \\
\hline & 3217 & 3 & 9,2 & 2,9 & 0,19 & 51 \\
\hline & 3539 & 1 & 3,4 & 1,3 & 0,54 & 19 \\
\hline & 3539 & 2 & 6,5 & 2,4 & 0,3 & 34 \\
\hline & 3532 & 3 & 9,3 & 3,42 & 0,21 & 47 \\
\hline \multirow{9}{*}{$\begin{array}{c}82: \\
18\end{array}$} & 2907 & 1 & 2,9 & 0,8 & 0,51 & 19 \\
\hline & 2903 & 2 & 5,9 & 1,7 & 0,24 & 41 \\
\hline & 2900 & 3 & 8,8 & 2,6 & 0,18 & 55 \\
\hline & 3215 & 1 & 3,1 & 1 & 0,56 & 18 \\
\hline & 3221 & 2 & 6,1 & 2 & 0,28 & 36 \\
\hline & 3224 & 3 & 9 & 2,7 & 0,21 & 43 \\
\hline & 3522 & 1 & 3,3 & 1,2 & 0,6 & 17 \\
\hline & 3529 & 2 & 6,4 & 2,3 & 0,32 & 31 \\
\hline & 3526 & 3 & 9,1 & 3,3 & 0,22 & 42 \\
\hline
\end{tabular}

\section{Pembahasan}

Dari Tabel 3 hasil pengujian didapat grafik torsi seperti pada Gambar 2, 3 dan 4.

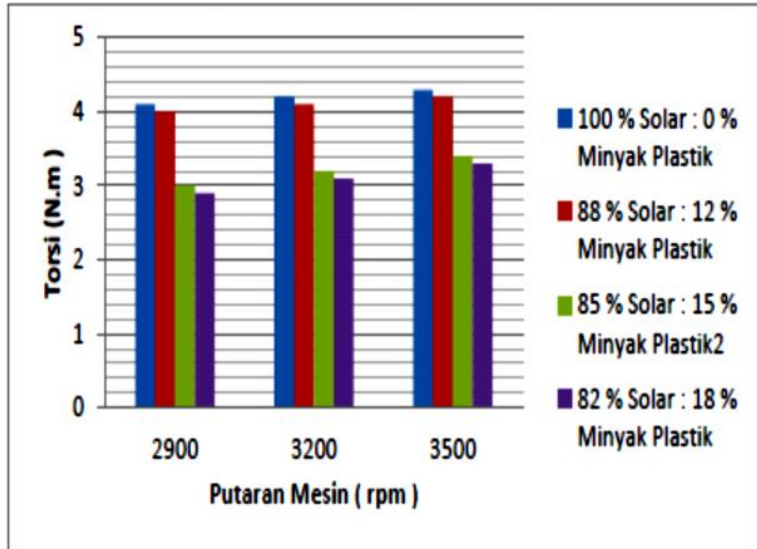

Gambar 2. Grafik Hubungan Torsi dengan Putaran Mesin pada pembebanan $1 \mathrm{~kg}$

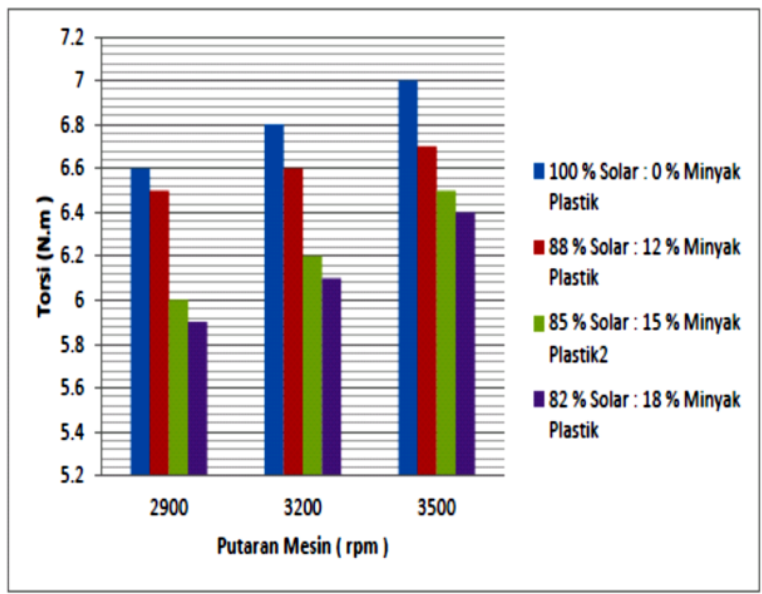

Gambar 3. Grafik Hubungan Torsi dengan

Putaran Mesin pada pembebanan $2 \mathrm{~kg}$

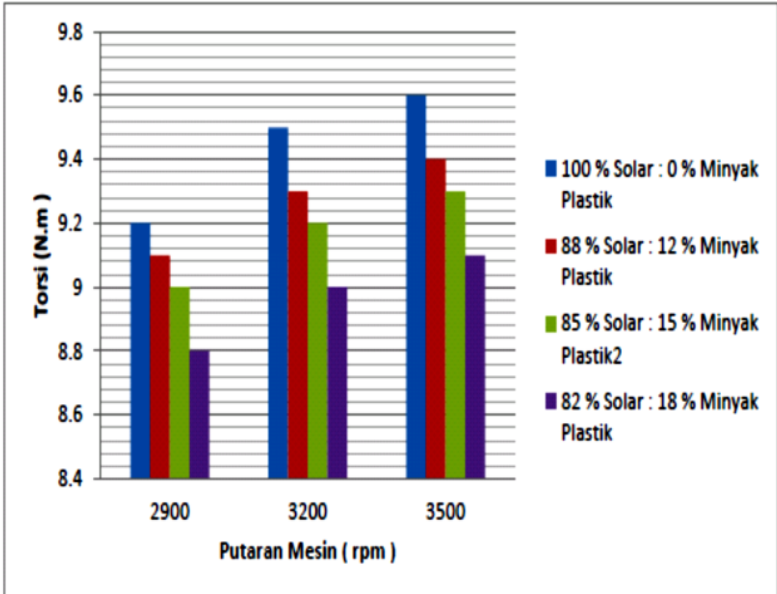

Gambar 4. Grafik Hubungan Torsi dengan Putaran Mesin pada pembebanan $3 \mathrm{~kg}$

Dari grafik-grafik hubungan torsi dengan putaran mesin diesel yang telah ditampilkan pada Gambar 2,3 dan 4, terlihat bahwa pada kondisi putaran mesin $2900 \mathrm{rpm}$ hingga $3500 \mathrm{rpm}$, torsi semakin besar seiring dengan semakin besar 
putaran mesin. Hal ini dikarenakan karakteristik/sifat-sifat dari minyak plastik yaitu viskositas, massa jenis dan nilai kalor, angka cetane, flash point yang berbeda dengan minyak solar [9]. Hal ini tidak sesuai dengan karakteristik dari mesin diesel itu sendiri, sehingga menyebabkan bahan bakar dengan campuran solar dengan minyak plastik akan lebih cepat terbakar/terbakar lebih dini, sebelum piston mencapai Titik mati Atas (TMA).

Dari Gambar 5,6, dan 7, menunjukan grafik daya yang dihasilkan terhadap putaran mesin pada pembebanan 1,2 dan $3 \mathrm{~kg}$ yang merupakan hasil perhitungan dari hasil pengujian torsi mesin diesel. Dari ketiga gambar tersebut dapat dianalisa bahwa daya yang dihasilkan mesin diesel dengan menggunakan bahan bakar solar 100\% dan variasi campuran bahan bakar antara solar dengan minyak plastik, yaitu berturut-turut $88 \%: 12 \%, 85 \%: 15 \%, 82 \%: 18 \%$, adalah semakin besar persentasi campuran minyak plastik didalam solar maka daya yang dihasilkan akan semaki kecil, baik pada pembebanan 1, 2 maupun $3 \mathrm{~kg}$. Namun yang dapat dicermati adalah semakin besar pembebanan, maka perbedaan daya yang dihasilkan akan semakin kecil. Hal ini dikarenakan torsi yang dihasilkan pada saat pengujian menunjukan hasil semakin kecil seiring semakin besar persentase campuran minyak plastik. Hal ini dikarenakan nilai kalor yang dihasilkan akan semakin kecil apabila minyak plastik dicampur dengan solar dengan persentase yang semakin besar seperti yang ditunjukan pada Tabel 2. Hasil penelitian yang sama juga ditunjukan oleh hasil penelitian untung, 2016, Sumarsono, 2011 dan Norsujianto, $2015[1,10,11]$.

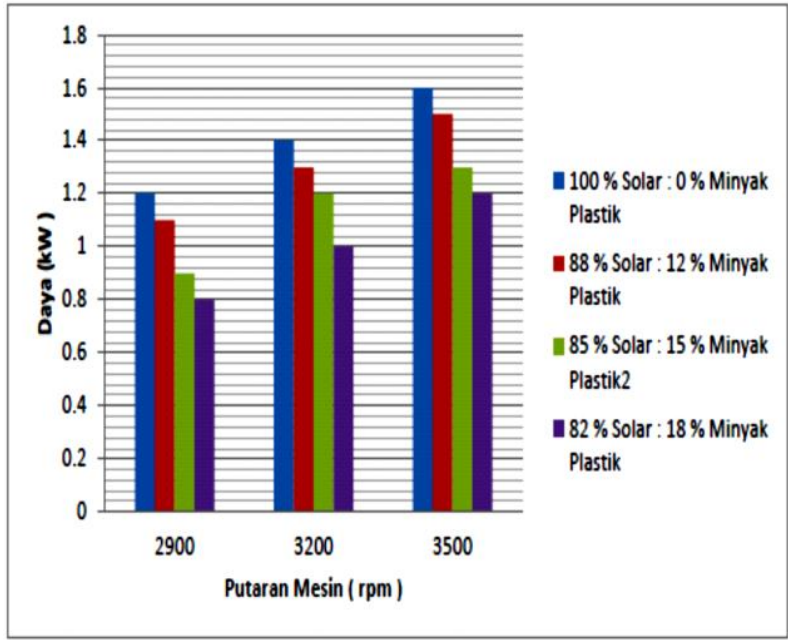

Gambar 5. Grafik Hubungan Daya dengan Putaran Mesin pada pembebanan $1 \mathrm{~kg}$

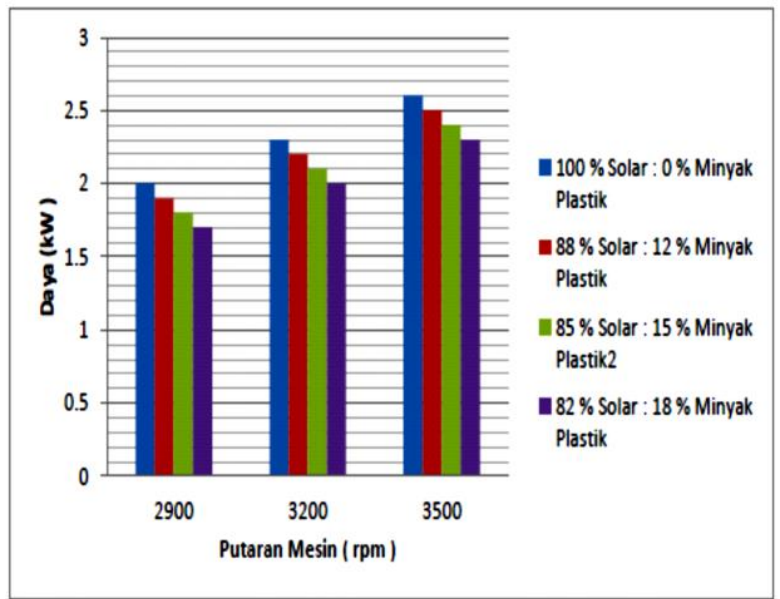

Gambar 6. Grafik Hubungan Daya dengan Putaran Mesin pada pembebanan $2 \mathrm{~kg}$

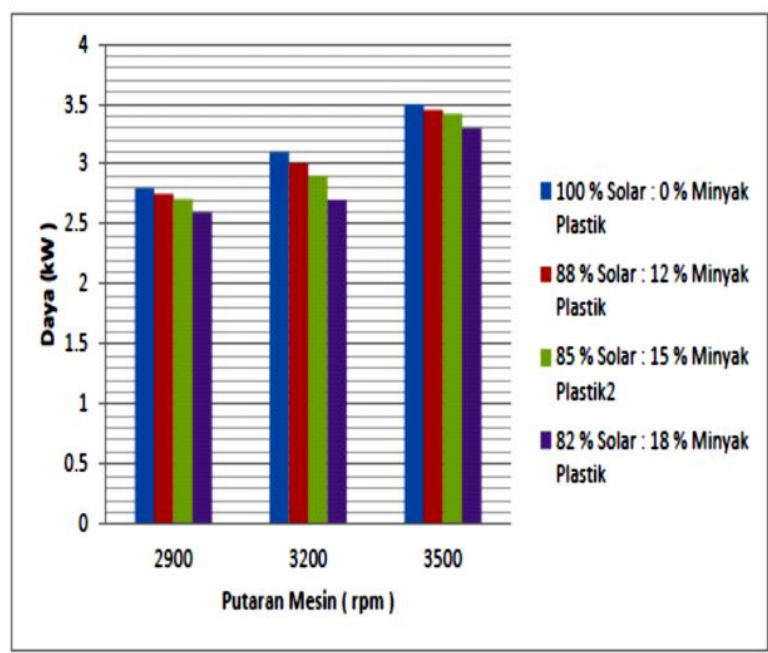

Gambar 7. Grafik Hubungan Daya dengan

Putaran Mesin pada pembebanan $3 \mathrm{~kg}$

Pada Gambar 8, 9 dan 10, dapat dianalisa bahwa konsumsi bakar spesifik meningkat seiring dengan meningkatnya 
campuran bahan bakar plastik pada putaran tinggi dan pembebanan yang semakin besar. Hal ini dikarenakan pada putaran tinggi mesin diesel dan beban yang semakin besar membutuhkan energi atau kalor masuk yang juga besar. Energi masuk ini berasal dari hasil pembakaran dari suply bahan bakar solar dan minyak plastik . Minyak plastik yang memiliki sifat mudah terbakar, sehingga mengakibatkan semakin tinggi persentasi campuran minyak plastik dalam bahan bakar akan menambah tinggi laju pembakaran yang terjadi, sehingga suply bahan bakar dalam silinder semakin besar. Nilai kalor yang lebih kecil dibandingkan nilai kalor pada campuran minyak plastik denan persentase tinggi, juga sangat mempengaruhi konsumsi bahan bakar spesifik pada mesin diesel. (Tabel 2).

Dari gambar 8, 9 dan 10, terlihat juga bahwa konsumsi bahan bahan bakar spesifik pada beban $1 \mathrm{~kg} /$ beban kecil (Gambar 8), konsumsi bahan bakar pada campuran solar dengan minyak plastik adalah $88 \%$ : $12 \%$, menunjukan perbedaan konsumsi bahan bakar yang signifikan dibandingkan pada campura solar dengan minyak plastik adalah $85 \%$ : $15 \%$ dan $82 \%$ : $18 \%$. Hal ini dikarenakan pada pembebanan $1 \mathrm{~kg}$, torsi yang dihasilkan jauh lebih besar pada kondisi putaran yang sama. Hal ini menunjukan bahwa mesin bekerja lebih ringan sehingga suply energi/bahan bakar lebih sedikit, namun dapat menghasilkan daya yang besar.

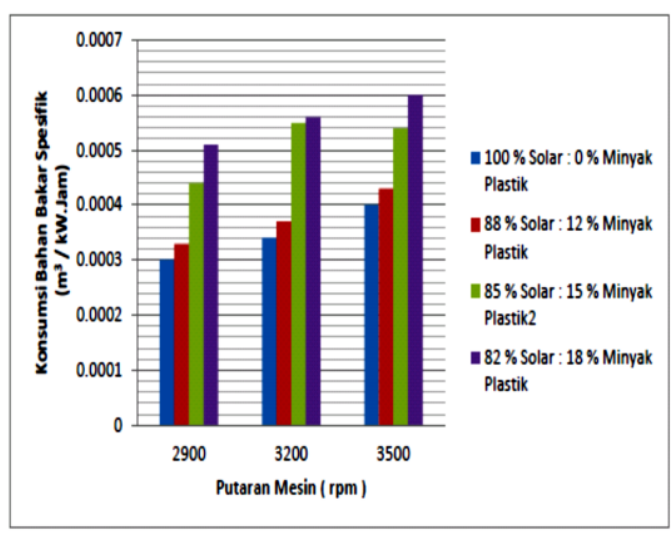

Gambar 8. Grafik Hubungan Konsumsi bahan Bakar Spesifik dengan Putaran

Mesin pada pembebanan $1 \mathrm{~kg}$

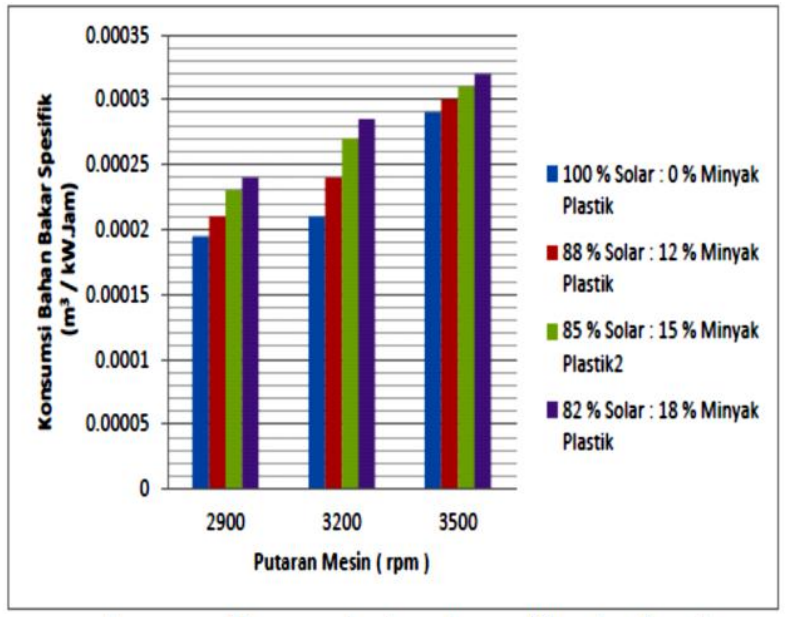

Gambar 9. Grafik Hubungan Konsumsi bahan Bakar Spesifik dengan Putaran

Mesin pada pembebanan $2 \mathrm{~kg}$

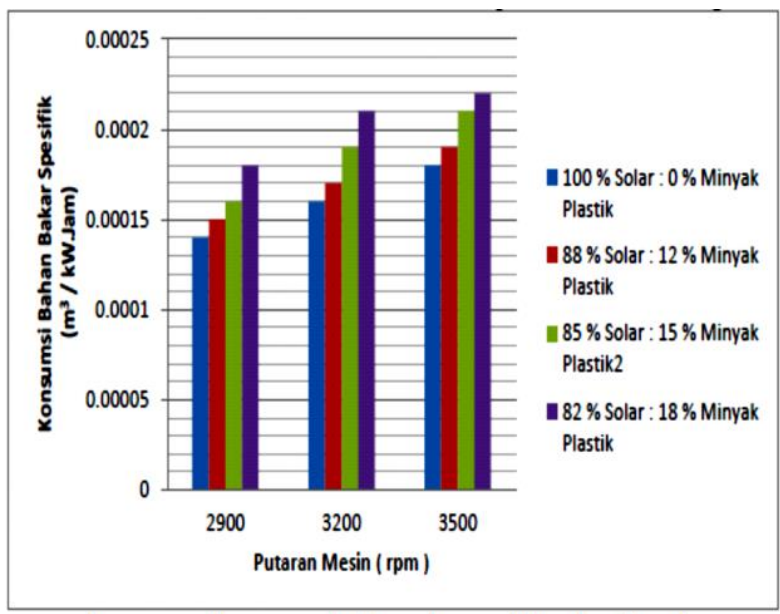

Gambar 10. Grafik Hubungan Konsumsi bahan Bakar Spesifik dengan Putaran

Mesin pada pembebanan $3 \mathrm{~kg}$

Hasil perhitungan dari efisiensi thermal yang terjadi pada mesin diesel dapat dilihat dari Gambar 11, 12 dan 13. Dari grafik-grafik tersebut terlihat bahwa efisiensi thermal yang terjadi pada pembebanan $1 \mathrm{~kg}$ juga menunjukan perbedaan hasil yang signifikan dari masing-masing variasi campuran. Hal yang berbeda apabila pada pembebanan besar dan putaran besar, efisiensi thermal menunjukan perbedaan yang kecil terutama pada penggunaan solar murni $(100 \%)$ dengan variasi campuran solar minyak plastik $88 \%: 12 \%$. 


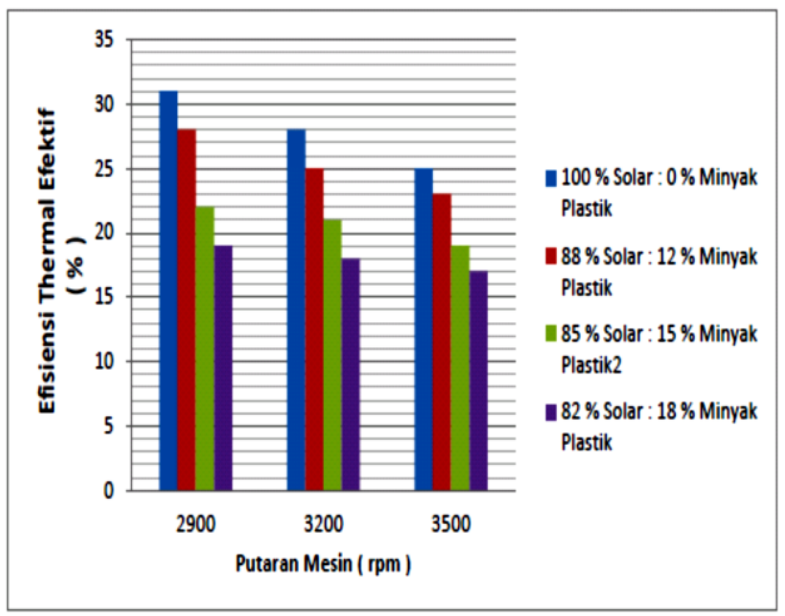

Gambar 11. Grafik Hubungan Efisiensi

Thermal dengan Putaran Mesin pada pembebanan $1 \mathrm{~kg}$

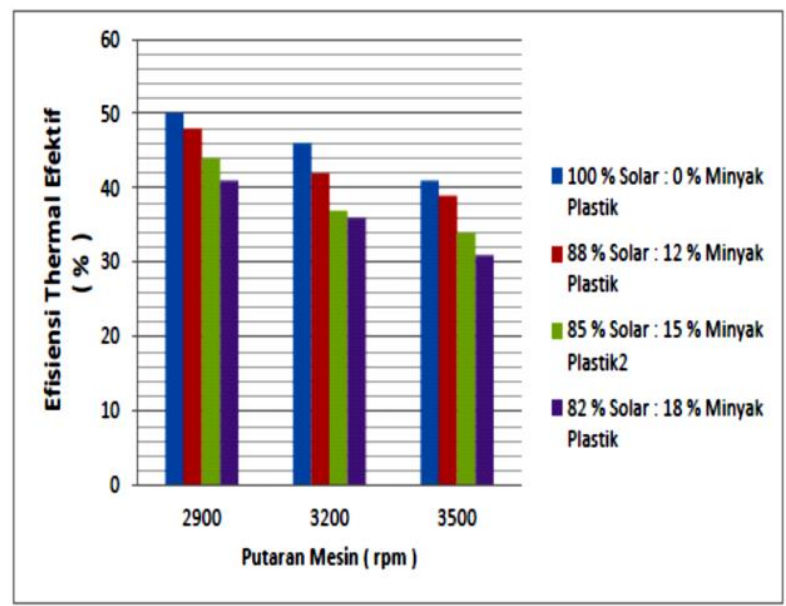

Gambar 12. Grafik Hubungan Efisiensi

Thermal dengan Putaran Mesin pada pembebanan $2 \mathrm{~kg}$

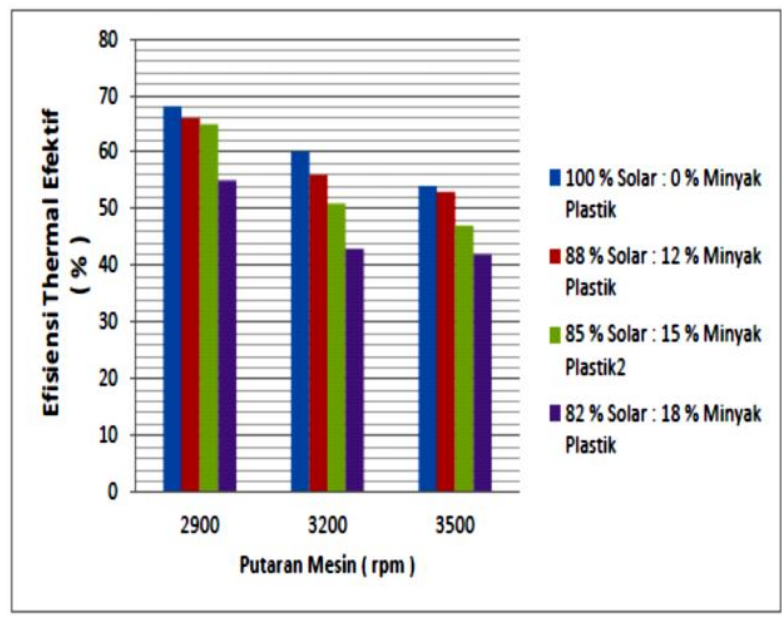

Gambar 13. Grafik Hubungan Efisiensi

Thermal dengan Putaran Mesin pada pembebanan $3 \mathrm{~kg}$

\section{KESIMPULAN}

Dari pemaparan diatas, maka kesimpulan yang dapat diambil dari penelitian yang telah dilakukan adalah minyak plastik dapat digunakan sebagai campuran bahan bakar solar untuk mesin diesel dengan daya yang dihasilkan cukup baik, terutama untuk kondisi putaran tinggi dan beban besar. Namun persentase minyak plastik yang digunakan untuk campuran bahan bakar solar sebaiknya tidak terlalu tinggi atau dengan kata lain hanya sebagai zat aditif atau penambah.

\section{UCAPAN TERIMA KASIH}

Kami mengucapkan terimah kasih kepada berbagi pihak yang terlibat dalam pembuatan minyak, Laboratorium Teknik Mesin UM Metro dan Laboratorium Motor Bakar UNILA.

\section{REFERENSI}

[1]. Untung Surya Dharma, Januari 2016, Pengaruh Penggunaan Limbah Plastik Sebagai Campuran Bahan Bakar Premium Terhadap Prestasi Mesin Sepeda Motor Merk-X, Prosiding Seminar nasional Teknoka, ISBN 978-60273919-0-1

[2]. Untung Surya Dharma, Juni 2015, Studi Eksperimental Analisa Karakteristik Minyak Plastik Hasil Dua Kali Proses Pirolisis, Jurnal Turbo, Volume IV, No. 1 2301-6663

[3]. Mahendra Fajri Nugraha, dkk, 2013, Pembuatan Fuel dari Liquid Hasil Pirolisis Plastik Polipropilen melalui Proses reforming Dengan katalis $\mathrm{NiO} / \mathrm{T}-\mathrm{Al}_{2} \mathrm{O}_{3}$, Jurnal Teknik Pomits, Vo. 2, No. 2, ISSN2337-3539 (2301-9271 Print)

[4]. Tamilkolundo, S \& Murugesan, C, April 2012, The Evaluation of Blend of Waste Plastic Oil- 
Diesel Fuel for Use as alternate fuel Transportation, 2nd International Conferrence on Chemical, ecology and Environmental Sciences (ICCEES'2012) Singapore

[5]. Aprian Ramadhan P, Munawar Ali, Pengolahan Sampah Plastik Menjadi Minyak menggunakan Proses Pirolisis, Jurnal Ilmiah Teknik Lingkungan, Vol.4, Nomor 1.

[6]. Santoso, Joko, 2010, Uji Sifat minyak plastic Pirolisis dan Uji Perormasi Kompor Berbahan Bakar Minyak Pirolisis dari Sampah Plastik.

[7]. Spesifikasi Minyak Solar. 1996-2009 PT. Pertamina (Persero) Corporate Website, 10 April 2016

[8]. Apriani, Putri, 2011, Tinjauan Terhadap Temperatur Operasi Pada Thermal Cracking Limbah Plastik Polytrene Untuk Menghasilkan Bahan Bakar Cair, Palembang, Jurnal Politeknik Negeri UNSRI : 4146.

[9]. Murni, 2012, Pengaruh Temperatur Solar Terhadap Performa Mesin Diesel Direct Injection Putaran Konstan, Jurnal Teknik Vol. 33 No. 1 Tahun 2012, ISSN : 0852-1697, Fakultas Teknik Universitas Diponegoro.

[10 Sumarsono, Markus, 2011, Analisa Pengaruh Campuran Bahan Bakar Solar-Minyak Jarak Pagar pada Kinerja Motor Diesel dan Emisi Gas Buang. Jurnal Teknologi Lingkungan, 2011, 9,2.

[11. Norsujianto, Tinton, 2015, Unjuk Kerja dan Emisi Gas Buang Motor Diesel Menggunakan
Bahan Bakar Campuran Minyak Hasil Pirolisis Limbah Plastik dan Biosolar Sebagai Bahan Bakar Alternatif, Jurnal Teknologi dan Industri (Diskontinu), 2015, 3.1 : 2332. 